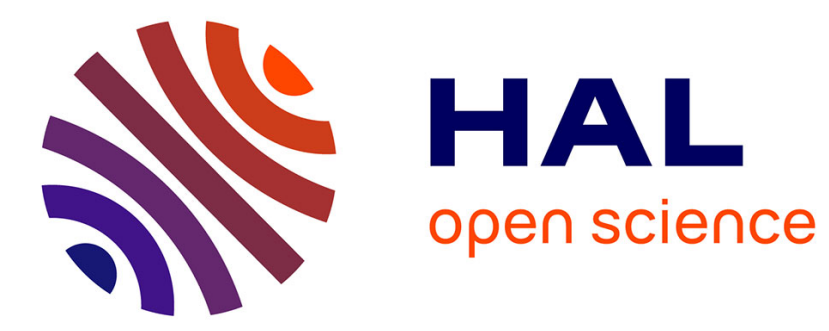

\title{
Simple optical resolution of terleucine
}

\author{
Joelle Pérard-Viret, Heiko Patzelt, André Collet
}

\section{To cite this version:}

Joelle Pérard-Viret, Heiko Patzelt, André Collet. Simple optical resolution of terleucine. Tetrahedron Letters, 1986, 27 (48), pp.5865-5868. 10.1016/S0040-4039(00)85348-4 . hal-03373537

\section{HAL Id: hal-03373537 https://hal.science/hal-03373537}

Submitted on 11 Oct 2021

HAL is a multi-disciplinary open access archive for the deposit and dissemination of scientific research documents, whether they are published or not. The documents may come from teaching and research institutions in France or abroad, or from public or private research centers.
L'archive ouverte pluridisciplinaire HAL, est destinée au dépôt et à la diffusion de documents scientifiques de niveau recherche, publiés ou non, émanant des établissements d'enseignement et de recherche français ou étrangers, des laboratoires publics ou privés. 


\title{
SIMPLE OPTICAL RESOLUTION OF TERLEUCINE
}

\author{
Joëlle Viret, Heiko Patzelt, and André Collet \\ Chimie des Interactions moléculaires, E.R. C.N.R.S. 285, Collège de France \\ 11, place Marcelin-Berthelot, 75005 Paris, France
}

Summary : Underivatized terleucine (1) can be conveniently resolved into its L- and D-enantiomers by recrystallization of its diastereoisomeric 10-camphorsulfonate salts.

We report the first simple optical resolution of terleucine (1) into its $\mathrm{L}$ - and D-enantiomers. This unusual amino acid has recently proved to be a valuable chiral inducer in various asymmetric syntheses. ${ }^{1-4}$ It has also been employed as a substitute for leucine or other amino acids in modified peptides (enkephalin, vasopressin and oxytoxin analogues). ${ }^{5-7}$

Since the first synthesis of DL-1 in $1914,^{8}$ several optical resolution procedures have been reported, in which the amino or acidic function has to be protected prior to interaction with the resolving agent. The $\mathrm{N}$-formyl ${ }^{9}$ and $\mathrm{N}$-tosyl ${ }^{10}$ derivatives have been resolved by crystallization of their brucine salts, the $\mathrm{N}$-acetyl ${ }^{11}$ and $\mathrm{N}$-benzyloxycarbony ${ }^{12}$ compounds by their cinchonidine and quinine (or quinidine) salts, respectively, whereas the methyl ${ }^{13}$ and ethyl ${ }^{10}$ esters have been separated as their dibenzoyltartrate salts. Apart from these methods which often have been reported to be tedious and/or inefficient, ${ }^{3}$ there is an ingenious asymmetric transformation whereby DL-1 can be converted to L-1 (60\%) in four steps through dipeptide formation with L-methyl glutamate, ${ }^{14}$ and two enzymatic processes, ${ }^{15,16}$ in which DL-terleucinamide or DL-N-phenylacetyl-1 are hydrolyzed to $\mathrm{L}-1$ in the presence of hog kidney amylase or penicillin-G-amidase, respectively.

The direct resolution of free amino acids is obviously a more attractive process than that involving prior introduction and subsequent cleavage of a protecting group. ${ }^{17 \text { a }}$ Strong acidic resolving agents are sometimes capable of forming, with neutral, unprotected amino acids, nicely crystalline

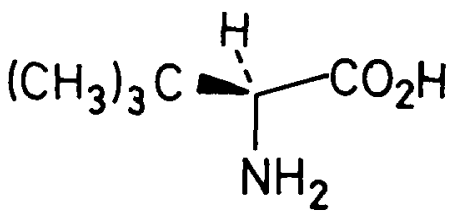

$L-1$

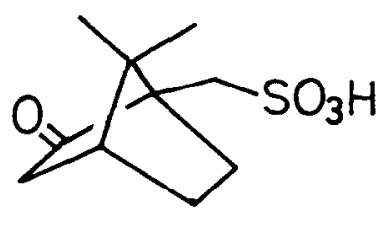

$(+)-2$

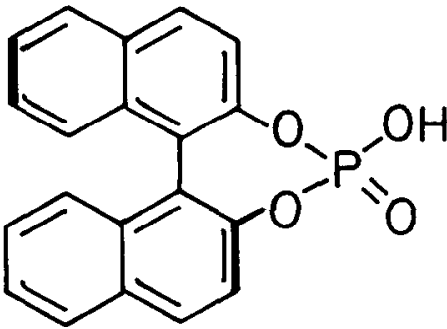

$S-(+)-3$ 
salts that are analogous in nature to amino acid hydrochlorides. For instance DL-phenylglycine ${ }^{18}$ and DL-o-tyrosine 19 have been efficiently resolved by formation of diastereoisomeric salts with 10-camphorsulfonic acid (CSA, 2) and binaphthylphosporic acid (BNP, 3), respectively. We have found that $\mathrm{DL}-1$ readily formed crystalline salts with both these chiral reagents in ethanol. BNP, however, revealed to be unsuitable for a complete separation, presumably due to the formation of unfavorable solid solutions between the diastereoisomeric salts. On the contrary, separation of the CSA salts proved quite satisfactory.

In order to optimize the resolution we first seeked for the main features of the ternary phase diagram of the diastereoisomeric CSA salts in $95 \%$ ethanol, at $20^{\circ} \mathrm{C}$ (Figure 1). ${ }^{17 \mathrm{~b}, 21}$ From the eutectic location (E), the solubility curve of the less soluble [(+)-CSA L-1] salt (EF) and the terminal solid solution range $(\mathrm{GH})$, the procedure described below was set up. In such a situation, the philosophy is to separate, at the very first crystallization, about $50 \%$ of a salt (A) whose composition would then roughly correspond to that of the solid solution boundary (H), from approximately the same weight of a salt (B) of nearly symmetrical composition in the mother liquors. Then $A$ is recrystallized (two or three times) until the desired enantiomeric purity is attained, while $B$ is cleaved back to partially resolved 1 ; the latter is combined with CSA of opposite sign to give new salt $C$, which is worked up like $A$.

Figure $1^{21}$

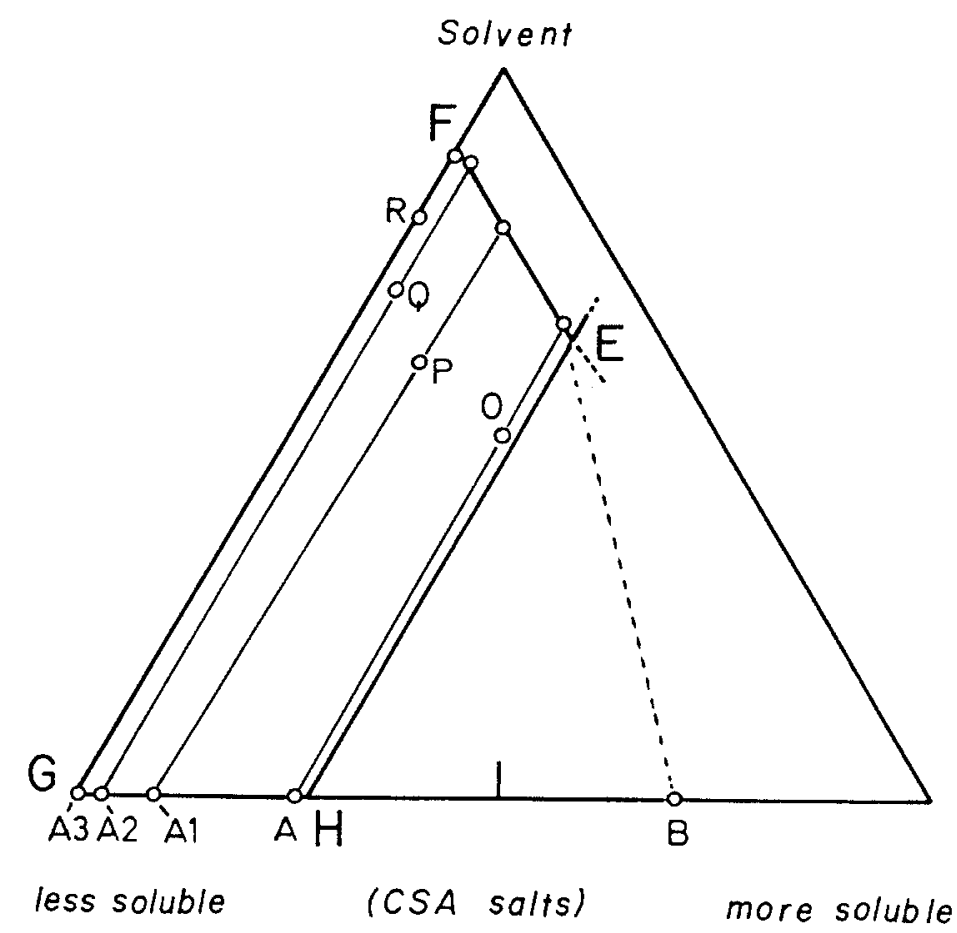


Hllustrative procedure. DL-Terleucine ${ }^{20}(20 \mathrm{~g}, 0.153 \mathrm{~mol})$ and $(+)$-CSA $(35.44 \mathrm{~g}, 0.153 \mathrm{~mol})$ were dissolved in hot $95 \%$ ethanol $(55.4 \mathrm{~g}$ ) and the solution (point $\mathrm{O}$ in Figure 1) was stirred in a thermostatted water bath $\left(20^{\circ} \mathrm{C}\right)$ overnight (minimum crystallization duration $10 \mathrm{~h}$ ). The solid was collected by suction filtration, washed with a small amount of absolute ethanol, and dried in air. Yield $23.5 \mathrm{~g}(43 \%)$ of salt A, m.p. ca. $188-195^{\circ} \mathrm{C}$ (by DSC). ${ }^{22}$ In order to determine the e.e. ${ }^{23}$ of 1 in this salt, ca. $150 \mathrm{mg}$ were cleaved by percolation through a Dowex $1 \times 2$ column (OH form) using $1 \mathrm{~N}$ acetic acid as the eluant; the recovered 1 showed $[\alpha]_{D}^{25}+14.5^{\circ}(\mathrm{AcOH}, \mathrm{c}=1)$, e.e. $\sim 47 \%$. The mother liquors evaporated to dryness ( $B$ in Figure 1 ) and cleaved back to terleucine by the same procedure yielded $10.8 \mathrm{~g}(54 \%)$ of 1 with $[\alpha]_{D}^{25}-13.2^{\circ}(\mathrm{ACOH}, \mathrm{c}=1)$, e.e. $\sim 43 \%$.

Recrystallization of A $(23.2 \mathrm{~g})$ in $95 \%$ ethanol $(34.8 \mathrm{~g}, \mathrm{P}$ in Figure 1$)$ at $20^{\circ} \mathrm{C}$ (overnight stirring) gave salt Al (14.2 g, 61\%), m.p. $189-198^{\circ} \mathrm{C}$, e.e. of $185 \%$; recrystallization of Al (13.9 g) in $32.4 \mathrm{~g}$ of ethanol (Q) yielded $\mathrm{A} 2(9.5 \mathrm{~g}, 68 \%)$, m.p. $204-207^{\circ} \mathrm{C}$, e.e. $95 \%$. Finally, recrystallization of A2 $(9.4 \mathrm{~g})$ from $36.4 \mathrm{~g}$ of ethanol (R) afforded A3 $(4.5 \mathrm{~g})$, m.p. $209-211^{\circ} \mathrm{C}$, which on cleavage (Dowex $1 \times 2(\mathrm{OH}), 1 \mathrm{~N} \mathrm{AcOH})$ furnished $1.5 \mathrm{~g}(95 \%)$ of $\mathrm{L}-1,[\alpha]_{\mathrm{D}}^{25}+30.0^{\circ},[\alpha]_{51+6}^{25}+36.0^{\circ},[\alpha]_{365}^{25}+110.1^{\circ}$ $(\mathrm{AcOH}, \mathrm{c}=1)$, e.e. $\geqslant 98 \%{ }^{24,25}$

On the other hand, the sample of terleucine recovered from the original mother liquors (B) $(10.2 \mathrm{~g})$ was combined with (-)-CSA $(18.1 \mathrm{~g})$ in $34.6 \mathrm{~g}$ of $95 \%$ ethanol, giving $17.6 \mathrm{~g}$ of salt Cl, e.e. ca. $80 \%$. Two recrystallizations of this salt as described above for Al eventually afforded salt C3 (6.6 g), m.p. $208-210^{\circ} \mathrm{C}$, from which $\mathrm{D}$-terleucine was recovered in $98 \%$ yield $(2.3 \mathrm{~g}) ;[\alpha]_{\mathrm{D}}^{25}-31.4^{\circ}$, $[\alpha]_{546}^{2.5}$ $-37.4^{\circ},[\alpha]_{365}^{25}-111.6^{\circ}(\mathrm{AcOH}, \mathrm{c}=1)$, e.e. $\geqslant 98 \% .^{24,25}$

The overall yield of pure L- and D-1 from DL-1 is ca. $23 \%$, without taking into account the partially resolved 1 which can be recovered in ca. $90 \%$ yield from the mother liquors by using the ion cxchange proccdure. The (+)- and (-)-CSA can be easily recovered from the resin by elution with dilute ammonia. This method is especially suitable for obtaining gram quantities $(1-10 \mathrm{~g})$ of resolved 1 in a short time (ca. 3 days overall) on a laboratory scale.

\section{References and Notes}

1) S. Hashimoto and K. Koga Chem. Pharm. Bull. 1979, 27, 2760.

2) H. Kogen, K. Tomioka, S. Hashimoto and K. Koga Ietrahedron 1983, 37, 3951.

3) U. Schöllkopt Tetrahedron 1983, 39, 2085.

4) U. Schöllkopf and R. Schever Liebigs Ann. Chem. 1984, 939.

5) J.-L. Fauchère and C. Peterman Ilelv. Chim. Acta 1980, 63, 825.

6) J. Pospisek and K. Blaha Coll. Czechoslov. Chem. Commun. 1977, 42, 1069.

7) M. Lebl, J. Pospisek, J. Hlavacek, T. Barth, P. Malon, L. Servitova, K. Hauser and and K. Jost Coll. Czechoslov. Chem. Commun. 1982, 47, 689.

8) F. Knoop and G. Landmann Z. physiol. Chem. 1914, 89, 157.

9) E. Abderhalden, W. Faust and E. Haase Z. physiol. Chem. 1934, 228, 187. 
10) D.A. Jaeger, M.D. Broadhurst and D.J. Cram 3. Am. Chem. Soc. 1979, 101, 717.

11) T. Tandue, S. Yajind and M. Imaida Chen. Pharm. Bull. 1968, 41, 2178.

12) T. Miyazawa, K. Takashima, Y. Mitsuda, T. Yamada, S. Kuwaka and H. Watanabe Bull. Chem. Soc. Jpn. 1979, 52, 1539.

13) H. Pracejus and S. Winter Chem. Ber. 1964, 97, 3173.

14) W. Steglich, E. Frauendorfer and F. Weygand Chem. Ber. 1971, 104, 687.

15) N. Izumiya, Shou-Cheng J. Fu, S.M. Birnbatum and J.P. Greenstein

J. Biol. Chem. 1953, 205, 221.

16) S. Grabley, M. Schlingmann (Hoechst A.-G.) Ger. Offen. DE 3,334,848;

Chem. Abstr. 1986, 104, 34334.

17) J. Jacques, A. Collet and S.H. Wilen "Enantiomers, Racemates and Resolutions",

J. Wiley \& Sons ed., New York, 1981; (a) p. 261; (b) p. 389.

18) A.W. Ingersoll J. Am. Chem. Soc. 1925, 47, 1168.

19) A. Garnier-Suillerot, J.-P. Abertini, A. Collet, L. Faury, J.-M. Pastor and L. Tosi

J. Chem. Soc., Dalton trans. 1981, 2544.

20) A combination of several reported procedures $8,10,12$ was found convenient for the synthesis of DL-1. To a well stirred mixture of $\mathrm{KMnO}_{4}(155 \mathrm{~g})$, $\mathrm{NaOH}(50 \mathrm{~g})$ and water $(500 \mathrm{ml})$, cooled in an ice-salt bath, was added dropwise $62.5 \mathrm{ml}$ of pinacolone at such a rate that the temperature did not exceed $0^{\circ} \mathrm{C}$. This operation was repeated three additional times in the same (5 1) flask. After MnOz had been separated off, the aqueous solution was acidified (HCL), and a solution of phenylhydrazine $(220 \mathrm{ml})$ in acetic acid $(400 \mathrm{ml})$ was slowly added with stirring. After 24 h standing the yellow precipitate was collected and recrystallized from $70 \%$ ethanol, yielding 356 g (87\%) of trimethylpyruvic acid phenylhydrazone, m.p. $172^{\circ} \mathrm{C}$. This phenylhydrazone was then hydrogenated to Dl-1 as described. 12

21) In the isothermal solubility diagram of figure 1, the compositions are expressed in g per $100 \mathrm{~g}$ of the whole mixture ( $\mathrm{g} \%$ ); solubility of the less soluble salt (F) in $95 \%$ ethanol, 20\% C, ca. $11 \mathrm{~g} \%$; eutectic composition (E), concentration ca. $34 \mathrm{~g} \%$, with $40 \%$ excess of the more soluble salt; solid solution boundary $(\mathbf{H})$ ca. $45 \%$ excess of the less soluble salt.

22) Melting point were recorded on a Perkin Elmer DSC2 differential microcalorimeter connected to a HP86 computer for data acquisition and processing; scanning rate $5 \mathrm{~K} / \mathrm{min}$, sample size ca. $1.5 \mathrm{mg}$. 23) The maximum rotation of 1 was considered to be $[\alpha]_{D}^{25} 30.7 \pm 0.7^{\circ}$ in glacial acetic acid, c=1, based on the chiral g.l.c. analysis of the final samples (see note 24 ); lit. $[\alpha]_{0}^{2.6}+30^{\circ}$ (acetic acid, c-1), ${ }^{12}$ and $[\alpha]_{D}^{25}+36^{\circ}$ (acetic acid, $c=2$ ), ${ }^{14}$ for L-terleucine.

24) The $\mathrm{N}$-trifluoroacetyl-isopropyl ester of this sample showed a single peak by g.l.c. analysis on a Chrompack S-Valine-S-phenylethylamide capillary column, $50 \mathrm{~m}$ length, $10^{\circ} \mathrm{C}$, carrier gas He 1.5 bar; a racemic sample was fully resolved under these conditions, with $\alpha, 1.037$ and the $D$ isomer first eluted; $1 \%$ of the other enantiomer in the resolved samples would have been detected. We thank I) R. Azerad (Faculté de Médecine, Paris) for these measurements.

25) No m.p. could be recorded by DSC for L-, D-, or DL-1, due to sublimation above $200^{\circ} \mathrm{C}$. 